\title{
IN VIVO STUDY OF GLUCOSE AND PROTEIN LEVELS USING THE DIABETIC WISTAR RAT MODEL
}

\author{
Goshen D. Miteu \\ BSc Biochemistry,Department of Biochemistry, Caleb University, Imota, Lagos, Nigeria
}

Correspondent: Goshen David Miteu

Adresss: Block A, Plot 6, Leadway Estate, Erunwen road, Ikorodu, Lagos

Article DOI: https://doi.org/10.36713/epra8692

DOI No: 10.36713/epra8692

\section{Background and Aims}

The diabetic animal model was developed as a type for studies in vivo because of the death rates in many countries associated with the prevalence of diabetes, this disease is a respecter of no person. This study assessed and compared total protein and albumin concentration, basal fasting blood sugar and post induction fasting blood sugar levels in rat model.

Methods

Qualitative and Quantitative test and analysis were carried to assess the levels of albumin and total protein and their absorbance levels were read and recorded in $\mathrm{g} / \mathrm{dL}$, while the fasting blood sugar was determined using the glucometer strip method at intervals and recorded in $\mathrm{mg} / \mathrm{dL}$. Group $A$ served as the negative, non-diabetic control for the study and they were fed normally with water without inducing diabetes while Group B served as the positive control, diabetic untreated group where Diabetes mellitus was induced using $150 \mathrm{mg} / \mathrm{kg}$ body weight of alloxan and left untreated.

Results

Plasma total protein in diabetic Wistar rat $(8.44 \pm 4.39 \mathrm{~g} / \mathrm{dl})$ did not change significantly $(P>0.05)$ compared with the control Wistar rat $(10.04 \pm 4.14)$. However, the level of 1-week post-induction FBS in diabetic Wistar rat $(475.75 \pm 66.74 \mathrm{mg} / \mathrm{dl})$ was significantly $(P<0.05)$ higher compared to that of the control $(85.0 \pm 6.7 \mathrm{mg} / \mathrm{dl})$.

\section{Conclusions}

Protein levels may not change within a week after developing diabetes mellitus and as such should not be the sole biomarker to test for diabetes.

KEYWORDS: Glucose metabolism, Protein metabolism, Glucose metabolism disorders, Protein metabolism disorders, Diabetes mellitus.

\subsection{INTRODUCTION}

All mammalian cells require glucose as a metabolic substrate. The predominant form made available to the cell for energy synthesis and other metabolic functions is D-glucose isomer. The glycolytic pathway is where glucose is broken down and delivered past the intestinal walls to the hepatic portal vein, where it is subsequently transported to the liver cells and other tissues. They can be transformed to fatty acids, amino acids (protein monomers), and glycogen, as well as oxidized by a variety of cellular 
catabolic mechanisms. Glucose is a key energy source for most tissues and organs, including the brain [1].

Hyperglycemia, on the other hand, is a sustained increase in blood glucose levels that can result in blindness, renal failure, vascular disease, and neuropathy. As a result, blood glucose levels must be kept under control and balanced. Glucose homeostasis is the process of maintaining a steady blood glucose level by regulating peripheral glucose uptake, hepatic glucose synthesis, and glucose uptake during carbohydrate absorption with the right hormones (Insulin and glucagon). This is accomplished by balancing a number of factors, including the rate of dietary carbohydrate intake and intestinal absorption, the rate of glucose utilization by peripheral tissues and glucose loss through the kidney tubule, as well as the rate of glucose removal or release by the liver and kidney. To prevent postprandial hyperglycemia (uncontrolled elevations in blood glucose levels after meals) and fasting hypoglycemia, the body uses insulin and glucagon to regulate blood glucose levels (decreased blood glucose levels during periods of fasting). Hormones, cytokines, and fuel substrates all have important activities that cellular processes detect. Diabetes mellitus is a long-term metabolic condition that affects various organs and hormonal pathways, compromising the body's ability to maintain glucose homeostasis. Long-term blood glucose elevations can lead to blindness, renal failure, heart and peripheral vascular disease, neuropathy, foot ulcers, and limb amputation, among other problems. In diabetic patients, vascular problems are the major cause of death [1].

Amino acids, which make up proteins, are made up of hundreds or thousands of smaller units. Peptide bonds connect the amino acids to form a protein molecule, which is made up of 20 different types of amino acids. The sequence of amino acids determines each protein's unique 3-dimensional shape and function, such as catalysis of biochemical events, mechanical support and immune defense, motility, ligand transport, nerve impulse transmission, and govern growth and differentiation [2]. Proteins contain polar, nonpolar, hydrophilic, hydrophobic, acidic, basic, aliphatic, and aromatic amino acids. A protein can acquire stable secondary structures such as the helix, -pleated sheet, -turn, and coils. The secondary structures are folded even more to form the tertiary structure, which is primarily stabilized by hydrogenbonding, electrostatic interactions, hydrophobic interactions, and van der Waals interactions. Proteins aren't entirely made up of solid atoms. They undergo conformational changes when they bind to a ligand.
Myoglobin and haemoglobin undergo conformational changes as they bind oxygen, allowing them to deliver oxygen to various tissues and lungs, respectively. As a result, these proteins have a structure-function link.

Proteins are used in bodybuilding since they carry out all of the body's major structural and functional functions. Protein structural abnormalities will result in molecular illnesses with significant metabolic function changes. Carbon, Hydrogen, Oxygen, and Nitrogen are the major 3components of proteins, whereas Sulfur and Phosphorus are minor components. Proteins have a lot of nitrogen in them. All proteins, on the other hand, are made up of the same building blocks: amino acids. Proteins are used in bodybuilding because they play a key structural and functional role in the body. Molecular disorders with substantial metabolic function alterations will emerge from protein structural abnormalities. Proteins are primarily composed of carbon, hydrogen, oxygen, and nitrogen, with tiny amounts of sulfur and phosphorus [2].

Diabetes mellitus is characterized by abnormalities in glucose metabolism. However, there is a scarcity of data on glucose and protein levels in diabetics. Diabetes is also linked to a variety of other comorbidities that are yet to be fully understood. As a result, this study is necessary to close the gap in the literature. The objective of this study is to determine in vivo the glucose and protein levels in diabetic Wistar rats by assessing insulin, glucagon, total protein and albumin levels in diabetic Wistar rats.

\subsection{INSULIN}

Insulin was discovered by Banting and Best at the University of Toronto in 1921-1922. It aids in the delivery of blood glucose into body cells, where it is digested for energy production. Insulin decreases blood glucose levels through boosting glucose uptake by muscle, liver, and fat cells. Exogenous insulin therapy is used to treat diabetes mellitus. Various forms of insulin with variable action times have been created for this purpose [1]. Insulin is the principal hormonal regulator of metabolism in the resting animal. In the absence of insulin, glucose absorption in tissues reduces but lipid mobilization in adipocytes increases. When insulin is absent, blood glucose levels rise; this medical condition is known as hyperglycemia [3].

\subsection{GLUCAGON}

Glucagon acts as a hyperglycemic, catabolic or an energy mobilization hormone in the body. Glucagon stimulates glucose release by the liver and maintains 
glucose homeostasis by binding to specific glucagon binding sites. It causes amino acids and fatty acids to be converted into ketone bodies through a negative feedback mechanism. When blood glucose levels return to normal, glucagon secretion stops. The inhibitory effects of somatostatin on glucagon secretion are more sensitive in ruminants than insulin.

When glucose concentrations are high, insulin and glucagon have an effect on carbohydrate metabolism. Insulin activates cells while glucagon inhibits them. The hormone glucagon encourages the liver to absorb amino acids from the blood and convert them to glucose. Through a negative feedback mechanism, rising blood glucose levels inhibit glucagon [1] to prevent insulin hypoglycemia as seen in tables 1 and 2 [3].

\subsection{ROLES OF INSULIN AND GLUCAGON IN GLUCOSE METABOLISM}

Metabolism involves catabolism which is the breakdown and anabolism which is the buid-up. The roles insulin and glugagon play in the synthesis and break down of glucose are explained below.

Glycogenesis is the primary enzyme that controls glycogen formation. It is activated by insulin and is linked to the level of glucose 6-phosphate. Insulin, unlike glucagon, slows down the breakdown of glycogen in muscle and liver tissues. Increased blood glucose limits glucagon output because cells believe there is already enough glucose in the blood and that more is unnecessary. Glucagon levels break down lipids, which strengthens the heart (preventing atherosclerosis and other cardiovascular disorders), increases blood flow in some tissues, particularly the kidneys, improves bile production, and slows gastric acid release [4,5]. This is to maintain a steady blood glucose level following carbohydrate consumption which is in line with the theory that maintaining blood glucose levels allows anabolism to occur [6,7].

\subsection{DIABETES MELLITUS}

Diabetes mellitus (DM) is a long-term glucose metabolism condition characterized by aberrant insulin function or insulin insufficiency [8,9]. Glucosuria occurs when glucose levels are at or below the threshold for hyperglycemia. Because of the lack of insulin, the cells become devoid of glucose and have to look for other sources of energy that can be mobilized $[10,11]$.

\subsection{CLASSIFICATION/TYPES OF DIABETES MELLITUS}

The aetiology and clinical presentation of diabetes mellitus are used to classify the disease. Type 1 diabetes is the most common type of diabetes in children, but it can strike anyone at any age. Type-1 diabetes is marked by a lack of insulin production and high blood glucose levels. People with T2DM require daily insulin injections to keep the disease under control [12].

\section{Type I diabetes mellitus (IDDM)}

Type I diabetes is defined by the sudden onset of severe symptoms, the need for exogenous insulin to maintain life, and the proclivity for ketosis even in the basal state. Type Ia is caused by immunological destruction of pancreatic $B$ cells, resulting in insulin insufficiency. Type Ib has no indication of autoimmunity, which normally defends the body against infection by detecting and eliminating bacteria, viruses, and other potentially harmful foreign substances $[13,14]$.

\section{Type II diabetes mellitus (NIDDM)}

Type 2 diabetes is a metabolic condition that causes increased blood glucose levels as a result of the body's inability to create enough insulin or failure to use the insulin it does make. Because it affects primarily persons over the age of 40 , this kind of diabetes was previously known as adult-onset diabetes. It is becoming more common in children, teenagers, and young adults, with type 2 diabetes accounting for $90 \%$ of all diabetes occurrences globally $[15,16]$.

\section{Gestational diabetes mellitus (GDM)}

Gestational diabetes mellitus develops during pregnancy, usually in the second or third trimester. The placenta causes insulin resistance in Gestational Diabetes as a result of hormonal changes. Approximately $2-10 \%$ of women develop this disease during pregnancy. Within 5-10 years, $30-40 \%$ of people with gestational diabetes would acquire type II diabetes.

\section{Other types}

Other type of diabetes mellitus: This is where diabetes mellitus is associated with other conditions, for example, pancreatic disease, hormonal disorders and drugs such as glucocorticoids and oestrogen-containing preparations. Depending on the ability of the pancreas to produce insulin, the patient may require oral agents or insulin. 


\subsection{METABOLIC DISORDERS IN DIABETES MELLITUS}

Metabolic diseases and aberrant tissues, organs, and systems are two types of linked disorders in DM. The organism as a whole live because of this dysfunction. Diabetes patients have showed symptoms of abnormalities in many types of metabolism, not just glucose metabolism, as the term implies.

\section{Carbohydrate Metabolism Disorders}

Disorders of carbohydrate metabolism clinically manifested by hyperglycemia, glycosuria, acidosis and hyperlactacedemic.

1. Hyperglycemia: Hyperglycemia occurs when a diabetic's blood glucose level surpasses the normal range. If fasting glucose level is consistently above $140 \mathrm{mg} / \mathrm{dL}(7.7 \mathrm{mmol} / \mathrm{l})$, it is a marker of impaired glucose tolerance. HPA levels can rise to $500 \mathrm{mg}$ percent (22 mmol / 1) in untreated patients, and 1000 $\mathrm{mmol} / \mathrm{l}$ or more in precoma stages.

2. Glucosuria: Glucosuria is a metabolic condition in which no glucose is discovered in the urine. It only develops after reaching a physiological renal threshold of roughly 180 $\mathrm{mg} / \mathrm{dL}$ (9.9 mmol/L) Individual differences exist as this threshold grows with age, so the glucosuria test should only be used as a guide for admission hyperglycemia.

3. Hyperlactacedemic: Hyperlactacedema is defined as an increase in blood MK concentration above normal (more than 16 $\mathrm{mg} \%$, or $1.3 \mathrm{mmol} / \mathrm{l})$. Causes: 1. Lactate oxidative catabolism in the Krebs cycle is inhibited; 2. Lactate glycogen re-synthesis is disrupted.

\section{Protein metabolism disorders}

1. Hyperasotemia is a condition in which blood nitrogenous substances (protein products of metabolism) are elevated above normal levels. Nitrogen protein has a typical concentration of $0.86 \mathrm{mmol} / \mathrm{l}$, while total nitrogen has a concentration of $0.87 \mathrm{mmol} / \mathrm{l}$. Causes: 1 . Increased protein catabolism; 2. Activation of the process of amino acid deamination in the liver as gluconeogenesis intensifies.

2. Azoturia occurs when the amount of DM in the urine increases

\section{Fat metabolism disorders}

Hyperlipidemia, ketonemia, and ketonuria are symptoms of lipid metabolism problems in people with diabetes.

1. Hyperlipidemia: Hyperlipidemia in diabetes mellitus is defined as a rise in blood total lipid levels above normal (more than $8 \mathrm{~g} / \mathrm{l}$ ). Hyperlipidemia can be caused by a number of factors. 1. Lipolysis activation in tissues 2 . Lipid cell waste inhibition 3. An increase in the production of cholesterol ketone bodies 4 . Increased fatty acids in cells as a result of vehicle deceleration 5. Lower LPLase activity.

2. Ketonemia is a condition in which the concentration of CT in the blood is higher than normal (more than $2.5 \mathrm{mg}$ percent). Acetone, acetoacetic acid, and -hydroxybutyric acid are all examples of CT. Ketoacemia is a common side effect of IDDM. The overall amount of $\mathrm{CT}$ in the blood might range from 30 to 50 milligrams per milliliter. Causes include: activation of lipolysis, increasing the rate of IVH oxidation in the cells, lipid synthesis inhibition, production of CT suppresses the oxidation of acetyl-CoA in hepatocytes.

3. Ketonuria is the excretion of ketone substances in the urine, which is thought to be a sign of a diabetic condition that is not improving. It is caused by a high quantity of ketone bodies in the blood, which is filtered well by the kidneys.

\subsection{EFFECTS OF DIABETES MELLITUS ON PROTEIN METABOLISM}

Insulin deficiency is a catabolic state for proteins. Insulin deprivation causes an increase in protein degradation and protein synthesis. There is a net protein loss during insulin deprivation because the magnitude of the increase in protein breakdown is greater than the decrease in protein synthesis after treatment. In poorly controlled type 1 diabetics, there is a rise in protein breakdown and protein synthesis [17].

Protein breakdown occurs mostly in skeletal muscle during insulin deprivation, while protein synthesis occurs in the splanchnic area. Glucagon, the hormone linked to increased energy expenditure and protein breakdown, may also play a part in the increase in protein synthesis that happens when the body is insulin deficient [18]. Ketoacids improve whole-body and skeletal muscle protein synthesis while decreasing nitrogen loss and leucine oxidation. The failure of whole-body or regional isotopic tracer experiments in 
type 1 diabetes individuals to properly demonstrate if insulin can increase protein synthesis highlights the need for research into insulin impact on individual protein synthesis. Because whole body or even regional tissue investigations provide a summation of the effects on individual proteins, the effects of insulin on protein synthesis rates are not seen [19].

\subsection{INDUCTION OF TYPE 1 DIABETES MELLITUS IN ANIMAL MODELS}

Rats, mice, hamsters, guinea pigs, and rabbits are ideal models which can be employed for experimentation in diabetic investigations and research. Chemicals (alloxan, streptozotocin, dithizone, monosodium glutamates, etc.) and viruses, and genetically diabetic rats are currently the best, most effective, and efficient ways to produce diabetes (type 1 diabetes) The main benefit of utilizing such substances is that body changes can be evaluated throughout and after diabetes induction [20].

\begin{abstract}
Alloxan
The most common chemical substance employed in diabetogenic studies is alloxan. It's been used to induce Type 1 diabetes in studies. Alloxan is a urea derivative that stimulates pancreatic islet - cells to necrotize [21]. By adjusting the dose of alloxan utilized, it has been widely used to create experimental diabetes in animals such as rabbits, rats, mice, and dogs with variable degrees of disease severity [22].
\end{abstract}

\section{Chemical Characteristics}

Intravenous administration delivers the drug directly to the targeted site and cells, resulting in a high level of effectiveness [23]. Tyrberg et al. 2001 [24] also noted that alloxan has been shown to be non-toxic to human beta-cells, even at very high dosages, because humans and rats have distinct glucose uptake pathways.

\section{Streptozotocin (STZ)}

Streptozotocin is a naturally occurring substance that is used in animal models to create Type 1 diabetes and Type 2 diabetes with several low doses. It's also used to treat metastatic cancer of the islets of Langerhans in medicine [25].

\section{Chemical Characteristics}

Streptozotocin enters the pancreatic cell by a glucose transporter called GLUT2 (Glucose transporter 2), which causes DNA to be alkylated. Furthermore, STZ causes activation of poly adenosine diphoshate ribosylation and nitric oxide production, which causes necrosis in pancreatic cells, resulting in insulindependent diabetes [26].

\subsection{MATERIALS}

Nine (9) healthy Wistar rats, animal cages, cotton wool, hand gloves, universal bottles, needles and syringes, standard digital scale, scissors, EDTA bottles, plain bottles, sample bottles rack, measuring cylinders, beakers, test tubes, automatic micropipette, pipettes, incubator, refrigerator, spectrophotometer, glucometer, detergent, permanent marker, commercial rat feed and water, centrifuge

\subsection{EXPERIMENTAL ANIMALS}

Nine (9) male healthy Wistar rats obtained from an animal house in Imota, Ikorodu were used for this study. The rats weighed between $200 \mathrm{~g}$ and 350 grams and were maintained in galvanized wire mesh cages, under hygienic conditions, freely ventilated and naturally illuminated animal rooms. They were made to acclimatize to the animal house condition for two weeks under laboratory conditions maintained at a temperature of $25^{\circ} \mathrm{C}$ and humidity of $50 \%$. The animals were maintained on standard commercial pelleted rat feed and also provided with clean water. The cages were cleaned daily and washed weekly.

\section{Chemicals}

Alloxan, fortress total protein assay kit, and fortress albumin assay kit. Alloxan was prepared according to the maufacturer's guide and the scope of the study.

\section{Experimental design}

In this experiment, a total ofifteen nine (9) Wistar rats were used. They were randomly divided into three (2) groups of five (5) rats. The blood glucose level was monitored at interval.

Group A: This group served as the negative, nondiabetic control for the study. The Wistar rats were not given alloxan. The Wistar rats were fed only normal feed and water ad-libitum.

Group B: This group served as the positive control, diabetic untreated group. Diabetes mellitus was induced in the Wistar rats using $150 \mathrm{mg} / \mathrm{kg}$ body weight of alloxan and left untreated.

\section{Determination of body weight}

The body weights of rats were determined using a standard digital scale. Body weights were measured and recorded. 


\subsection{EXPERIMENTAL INDUCTION OF DIABETES MELLITUS}

The rats were subjected to a 12-15 hours overnight fast and diabetes induced by a single intra-peritoneal injection of $150 \mathrm{mg} / \mathrm{kg}$ body weight alloxan monohydrate dissolved in $0.9 \%$ normal saline. Since alloxan is capable of producing fatal hypoglycaemia as a result of massive pancreatic insulin release, the rats were treated with $2 \mathrm{ml}$ of $10 \%$ glucose solution using orogastric tube 4 hours after induction. Diabetes was confirmed after two days (48hours) in animals with fasting blood glucose level (FBGL) above $250 \mathrm{mg} / \mathrm{dl}$ which were selected for the experiment.

\subsection{ESTIMATION OF ALBUMIN}

Principle: The test is used for quantitative determination of albumin in serum, serum albumin binds with the bromocresol green indicator in an acid medium to forma green BCG complex, the amount of which is directly proportional to the albumin concentration present in that sample.

Procedure: $1000 \mu \mathrm{l}$ of reagent and $5 \mu \mathrm{l}$ of Demineralized water was pipetted into a plain sample bottle labelled with blank. $1000 \mu$ l of reagent and $5 \mu 1$ of standard reagent was pipetted into a plain sample bottle labelled with standard, then $1000 \mu \mathrm{l}$ of reagent and $5 \mu \mathrm{l}$ of each of the plasma of the 9-blood sample collected was pipetted into a plain sample bottle labelled with their corresponding tag. The whole samples, including the blank and standard were incubated for 5 minutes at $25^{\circ} \mathrm{C}$. The absorbance of the sample and standard was then measured at $600 \mathrm{~nm}$ against the reagent blank.

\subsection{ESTIMATION OF TOTAL PROTEIN}

Principle: Copper ions reaction alkaline solution with protein peptide bonds to give a purple-colored biuret complex. The amount of complex formed is directly proportional to the amount of protein in the specimen.

Procedure: $1000 \mu 1$ of reagent and $20 \mu 1$ of Demineralized water was pipetted into a plain sample bottle labelled with blank. $1000 \mu 1$ of reagent and $20 \mu 1$ of standard reagent was pipetted into a plain sample bottle labelled with standard, then $1000 \mu \mathrm{l}$ of reagent and $10 \mu \mathrm{l}$ of each of the plasma of the 9 blood sample collected was pipetted into a plain sample bottle labelled with their corresponding tag. The whole samples, including the blank and standard were incubated for 10 minutes at $25^{\circ} \mathrm{C}$. The absorbance of the sample and standard was then measured at $500 \mathrm{~nm}$ against the reagent blank

\subsection{ESTIMATION OF GLUCOSE LEVEL}

Principle: glucometers use test strips containing glucose oxidase, an enzyme that reacts to glucose in the blood droplet, and an interface to an electrode inside the meter, When the strip is inserted into the meter, the flux of the glucose reaction generates an electrical signal. "The glucometer is calibrated so the number appearing in its digital readout corresponds to the strength of the electrical current: The more glucose in the sample, the higher the number.

Procedure: The tail of each rats was cut with a surgical scissors and a drop of blood was placed on the disposable test strip that has been inserted to the glucometer, The values were recorded.

\subsection{RESULTS}

As illustrated in Figure 4.1, the total protein concentration in the plasma of the diabetic Wistar rat $(8.444 .39 \mathrm{Mg} / \mathrm{dl})$ did not differ substantially $(\mathrm{P}>0.05)$ from that of the control Wistar rat (10.04 4.14 Mg/dl). When comparing the albumin levels of diabetic Wistar rats $(1.720 .41 \mathrm{Mg} / \mathrm{dl})$ to those of the control rats $(1.58$ $0.13 \mathrm{Mg} / \mathrm{dl}$ ) in Figure 4.2, it was found that there was no significant difference $(\mathrm{P}>0.05)$. Figure 4.3 shows that there was no statistically significant difference ( $>0.05)$ between the levels of Basal FBS in diabetic Wistar rats $(88.02 .2 \mathrm{Mg} / \mathrm{dl})$ and controls $(84.24 .4$ $\mathrm{Mg} / \mathrm{dl}$ ) in diabetic Wistar rats. According to Figure 4.3, the level of FBS in diabetic Wistar rats at one week post-induction was substantially higher (P0.05) than the level in the control group (85.0 $6.7 \mathrm{Mg} / \mathrm{dl})$, indicating that the diabetic Wistar rat was diabetic.

\subsection{DISCUSSIONS}

Specifically, the results of nine male wistar rats were examined. The mean values for total protein, albumin, basal FBS, and post-induction FBS in alloxan-induced wistar rats were determined. The statistical programme for social sciences was used to compare the total protein and albumin concentrations in healthy and diabetic Wistar rats. In the experimental class and the controls, there was no substantial difference comparing the basal fasting blood sugar and the post-induction fasting blood sugar levels. The findings revealed that the total protein and albumin concentrations were the same in both groups of participants. As a result, it is reasonable to conclude that blood protein and albumin levels are not important indicators for the diagnosis of diabetes. Induced alloxan in rats has the ability to elevate glucose blood levels [26] which is consistent with the statistically significant high values for post-induction FBS found in our study. 
Alloxan is a urea derivative that produces selective necrosis of the -cells of the pancreatic islets when administered intravenously [21]. In the experiment, diabetes was confirmed after two days of induction (48 hours) in mice with fasting blood glucose levels greater than $250 \mathrm{mg} / \mathrm{dL}$, which were initially selected for the experiment. That alloxan can cause diabetes by damaging the pancreatic islets that contain insulin, which is important for controlling blood glucose levels, has been demonstrated [27].

As a result, we can conclude that the current study is consistent with prior studies and reports in that induced alloxan is capable of triggering inflammatory activities in the pancreas through the death of pancreatic cells. The increased urinary activity that some Diabetic mellitus patients experience can help to dilute proteins in their urine.

Diabetes can be diagnosed by measuring the level of glucose in the blood, preferably while fasting, because hyperglycemia is a significant marker for the disease, which is characterised by insulin secretion deficit, pancreatic cell malfunction, and insulin resistance in body cells. Serum proteins, on the other hand, cannot be utilized to make a diagnosis of diabetes by themselves.

\section{CONFLICT OF INTEREST}

The author declares no conflict of interest in this research.

\section{REFERENCES}

1. Sicree R, Shaw J and Zimmet P. The Global Burden. Diabetes and Impaired Glucose Tolerance. Prevalence and Projections. In: Gan, D. ed. Diabetes Atlas, 3rd edn. Brussels: International Diabetes Federation 2006; pp. 16-103.

2. Nair KS, Garrow JS, Ford C, Mahler RF, Halliday D. Effect of poor diabetic control and obesity on whole body protein metabolism in man. Diabetologia 1983; 25(5):400-3. [PubMed] [Google Scholar]

3. Frayn, K. N. Metabolic regulation: A human perspective 2009; (3rd ed.). Oxford: University of Oxford.

4. Dimitriadis, G., \& Newsholme, E. Integration of biochemical and physiologic effects of insulin on the control of blood glucose concentrations. In D. LeRoith, S. Taylor, \& J. Olefsky (Eds.), Diabetes mellitus: A fundamental and clinical text (3rd ed., 2004; pp. 183-197). Philadelphia, PA: Lippincott Williams \& Wilkins.

5. Newsholme, E., \& Dimitriadis, G. Some thoughts on the importance of insulin in the regulation of the blood glucose level. Experientia, 2004; 52, 421-425. http://dx.doi.org/10.1007/BF01919310
6. Dashty, M. A quick look at biochemistry: Carbohydrate metabolism. Clinical Biochemistry. 2013; 46, 1339-1352. http://dx.doi.org/10.1016/j.clinbiochem.2013.04.027

7. Gardner, G., McGilchrist, P., \& Pethick, D. Ruminant glycogen metabolism. Animal Production Science, $\quad 2014 ; \quad 54, \quad 1575-1583$. http://dx.doi.org/10.1071/AN14434

8. Centers for Disease Control and Prevention. Prevalence of Diabetes and Impaired Fasting Glucose in Adults - United States, 1999-2000. 2002; MMRW, 52.

9. Wild, S, Roglic, G, Green, A, Sicree, R, King, $H$. Global prevalence of diabetes: estimates for the year 2000 and projections for 2030. Diabetes Care 2004; 10, 2568-9.

10. Piero MN, Njagi JM, Kibiti CM, Ngeranwa JJN, Njagi ANM, Njue WM and Gathumbi PK. Herbal management of diabetes mellitus: a rapidly expanding research avenue Int J Curr Pharm Res, 4 2012; (2):1-4.

11. Belinda $R$. Gale Encyclopaedia of Alternative Medicine. 2004; pp 2603-2605.

12. Cefalu WT. Concept, strategies, and feasibility of noninvasive insulin delivery. Diabetes Care. 2004; 27(1): 239-246.

13. Nolte M.S. and Karam, J.H. Pancreatic hormones and anti-diabetic drugs. In: Basic and Clinical Pharmacology, 8th edition. Katzung B.G. Lange Medical Books. Mc Graw-Hill, San Francisco. USA 2001; pp. $711-734$.

14. Modi P, Mihic M, Lewin A. The evolving role of oral insulin in the treatment of diabetes using a novel RapidMistTM System. Diabetes Metab Res Rev 18 (Suppl 1): 2002; S38-S42. 11

15. Gerich. J.E. Matching Treatment to Pathophysiology in type 2 Diabetes. Clinical Therapeutics. Vol.23, No 5. 2001; pp. 646-659.

16. Nygren J, Nair KS. Differential regulation of protein dynamics in splanchnic and skeletal muscle beds by insulin and amino acids in healthy human subjects. Diabetes 2003; $\quad 52(6): 1377-$ 85. [PubMed] [Google Scholar]

17. Autoimmune Disease Coordinating Committee. Progress in Autoimmune Diseases Research. Bethesda, 2005; MD: National Institute of Diabetes and Digestive and Kidney Diseases.

18. Jaleel A, Nehra V, Persson XM, Boirie Y, Bigelow $M$, Nair KS. In vivo measurement of synthesis rate of multiple plasma proteins in humans. Am J Physiol Endocrinol Metab. 2006; 291(1): E1907. [PubMed] [Google Scholar]

19. Mendez JD, Ramos HG. Animal models in diabetes research. Archives of medical research 1994; 25(4):367-75.

20. Etuk EU, N. J. Animals models for studying diabetes mellitus. Agric Biol 2010; 1:130-4. 


\section{EPRA International Journal of Research and Development (IJRD)}

Volume: 6 | Issue: 10 | October 2021
- Peer Reviewed Journal
21. Iranloye BO, Arikawe AP, Rotimi G, Sogbade AO. Anti-diabetic and anti-oxidant effects of Zingiber officinale on alloxaninduced and insulin-resistant diabetic male rats. Nigerian journal of physiological sciences: official publication of the Physiological Society of Nigeria 2011; 26(1):89-96

22. Federiuk IF, Casey HM, Quinn MJ, Wood MD, Ward WK. Induction of type-1 diabetes mellitus in laboratory rats by use of alloxan: route of administration, pitfalls, and insulin treatment. Comparative medicine 2004; 54(3):252-7.

23. Tyrberg B, Andersson A, Borg LA. Species differences in susceptibility of transplanted and cultured pancreatic islets to the beta-cell toxin alloxan. General and comparative endocrinology 2001; 122(3):238-51.

24. Brentjens R, Saltz L. Islet cell tumors of the pancreas : the medical oncologist's perspective. The Surgical clinics of North America. 2001; 81(3):527-42.
25. Patel $R$, Shervington A, Pariente JA, MartinezBurgos MA, Salido GM, Adeghate E, et al Mechanism of exocrine pancreatic insufficiency in streptozotocin-induced type 1 diabetes mellitus. Annals of the New York Academy of Sciences 2006; 1084:71-88.

26. Mythili MD, Vyas R, Akila G, Gunasekaran S. Effect of streptozotocin on the ultrastructure of rat pancreatic islets. Microscopy research and technique 2004; 63(5):274-81.

27. Kliber A, Szkudelski T, Chichtowska J. Alloxan stimulation and subsequent inhibition of insulin release from in situ perfused rat pancreas. Journal of physiology and pharmacology: an official journal of the Polish Physiological Society 1996; 47(2):321-8.

Table 1: Action of some hormones (Shrayyef \& Gerich, 2010)

\begin{tabular}{|c|c|c|c|}
\hline Hormones & Glucose production & Glucose utilization & Lipolysis \\
\hline Insulin & Decrease & Increase & Decrease \\
\hline Glucagon & Increase & - & - \\
\hline Epinephrin & Increase & Decrease & Increase \\
\hline Cortisol & Increase & Decrease & Increase \\
\hline Growth hormone & Increase & Decrease & Increase \\
\hline Free fatty acids & Increase & Decrease & - \\
\hline
\end{tabular}

Table 2: Mechanism of action of key metabolic regulators (Shrayyef \& Gerich, 2010)

\begin{tabular}{|l|l|l|l|l|l|l|}
\hline Pathway & Insulin & glucagon & Epinephrin & T3, T4 & Cortisol & $\begin{array}{l}\text { Growth } \\
\text { hormone }\end{array}$ \\
\hline Glycolysis & + & - & + & + & - & - \\
\hline Glycogenesis & + & - & - & - & + & + \\
\hline glycogenolysis & - & $+{ }^{\prime}$ 'liver" & $+{ }^{\prime}$ L \&M" & + & - & + \\
\hline Gluconeogenesis & - & + & + & + & + & + \\
\hline Lipogenesis & + & - & - & - & + 'central' & - \\
\hline Lipolysis & - & + & + & + & + 'peripheral & + \\
\hline Protein synthesis & + & - & - & + & + & ++ \\
\hline Proteolysis & - & + & & & & \\
\hline
\end{tabular}

Note: $(+)$ stimulated, $(-)$ inhibited. 


\section{EPRA International Journal of Research and Development (IJRD)}

Volume: 6 | Issue: 10 | October 2021

- Peer Reviewed Journal

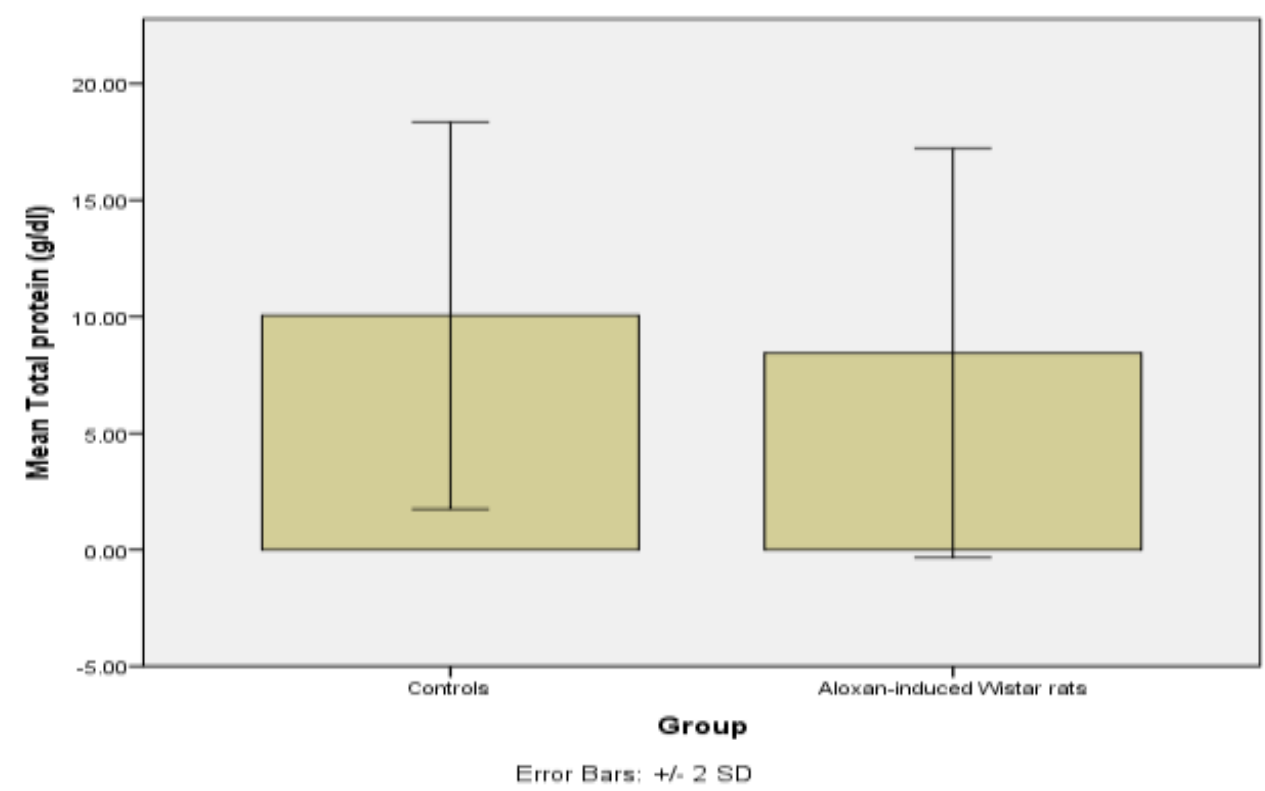

Figure 4.1: Levels of Total protein in Diabetic Wistar rats and Controls

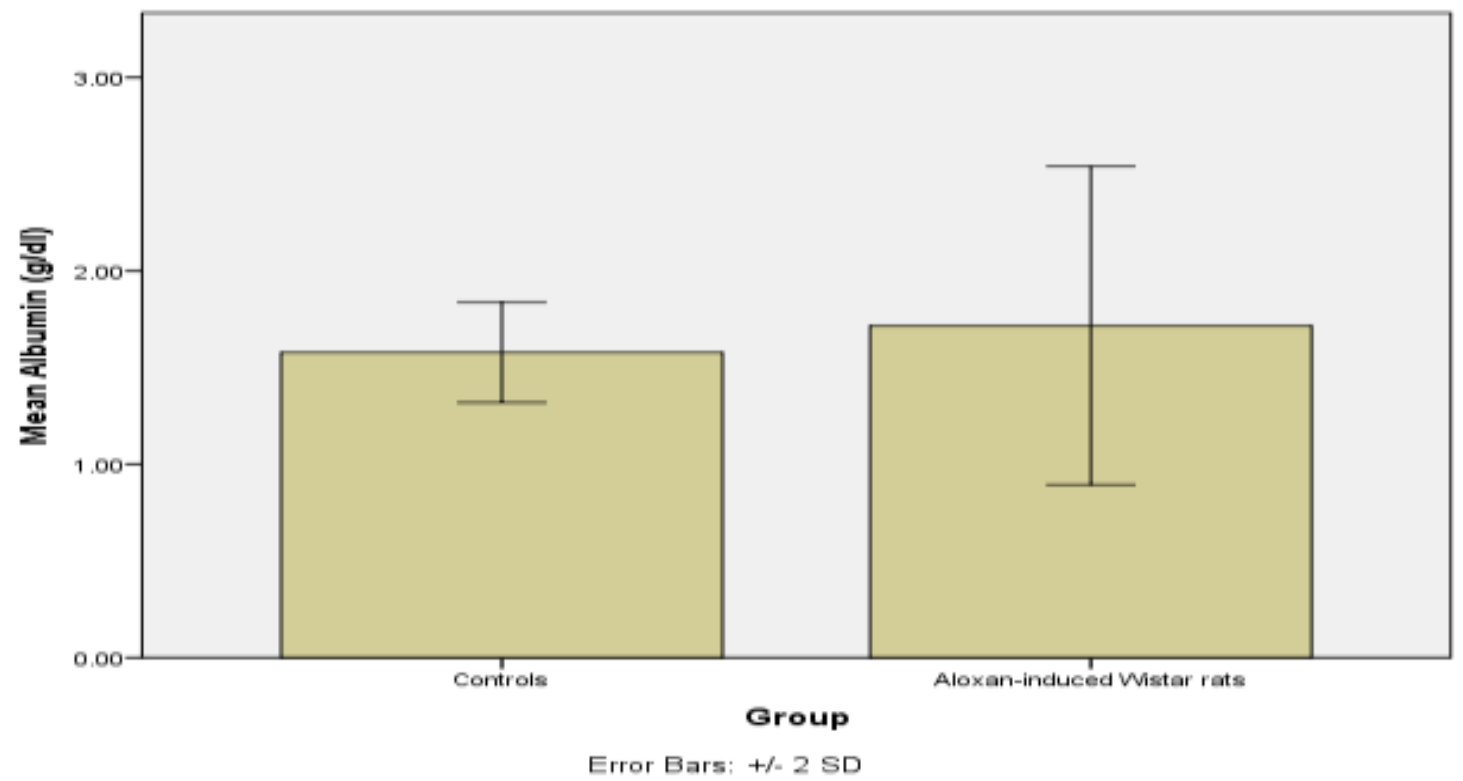

Figure 4.2: Level of total albumin in controls and diabetic patients 


\section{EPRA International Journal of Research and Development (IJRD)}

Volume: 6 | Issue: 10 | October 2021

- Peer Reviewed Journal

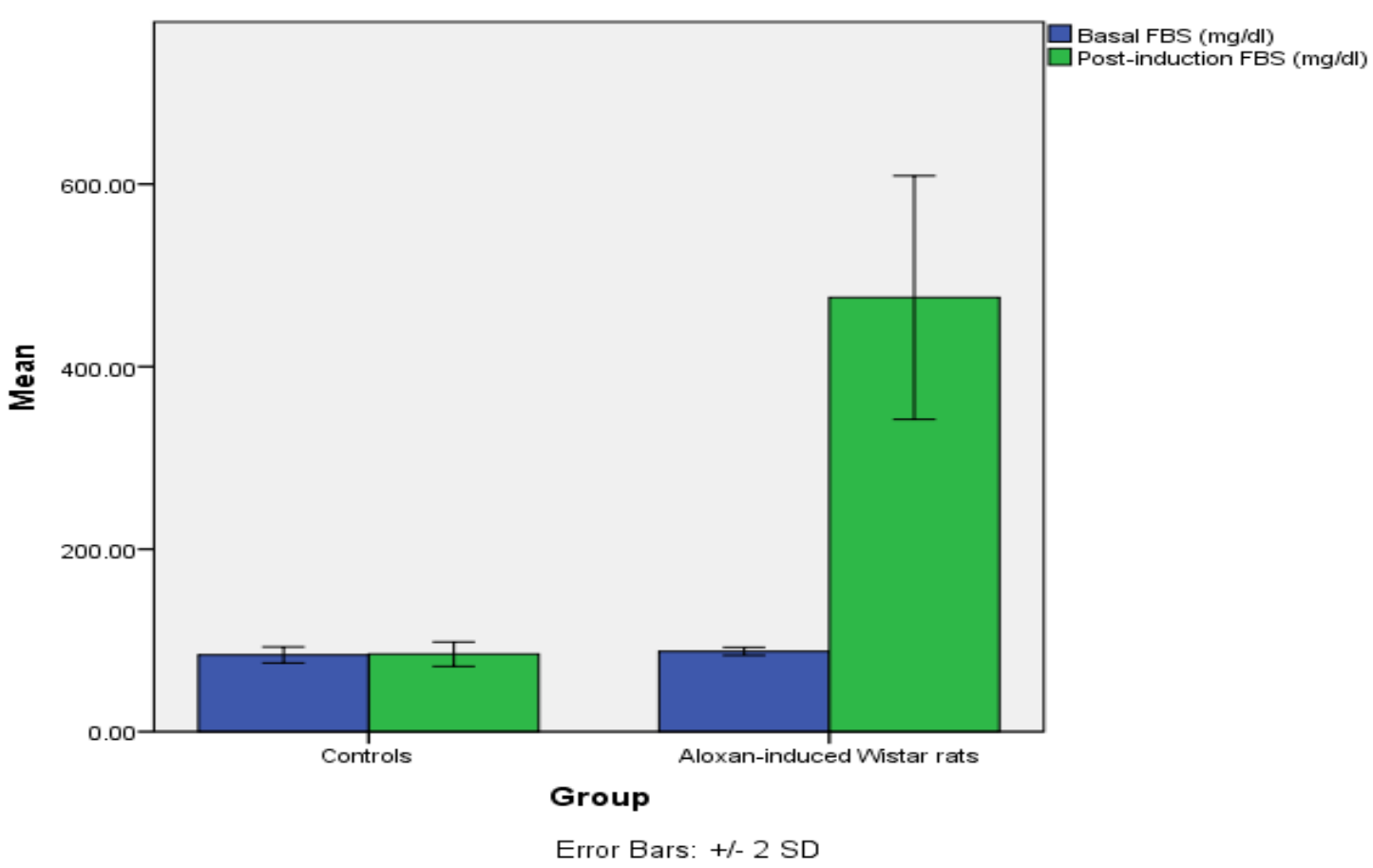

Figure 4.3: Alloxan induced rat and controls

\section{Research Highlights}

- Damage and Improper functioning of the pancreatic cells can lead to diabetes

- Blood protein and albumin levels are not important biomarkers for the diagnosis of diabetes

- Diabetes can be diagnosed by measuring the level of glucose in the blood, preferably while fasting 